\title{
COMPARATIVE STUDY OF MANAGEMENT OF CLOSED COMMINUTED FEMORAL SHAFT FRACTURES WITH CLOSED INTERLOCKING INTRAMEDULLARY NAIL AND OPEN REDUCTION AND DYNAMIC COMPRESSION BRIDGE PLATING
}

\begin{abstract}
Shrestha $\mathbf{B}^{*}$, Kumar $\mathbf{P}^{*}$, Singh G K
ABSTRACT

Fracture shaft of the femur are life-threatening injuries and can cause severe permanent disability. Nowadays die interlocking nailing is regarded as the operative technique of choice for fracture shaft of femur. However, the advantages and disadvantages have rarely been compared with plate osteosynthesis. This is prospective study to compare the two methods of treatments in terms of time to union, hospital slay (including readmission), wound infection, shortening of limb, delayed union, malunion, joint stiffness and implant failure. 54 patients, age (16 to 66) years, were treated by DCP (22), and interlocking nail (24). Eight patients were lost to follow up. The study was conducted in Services Hospital, Department of Orthopaedics and Ittefaq Hospital, Lahore, Pakistan from June 1996 to Dec 1997. Written consent was taken regarding the type of surgery to be performed. Open fractures of Gustilo Grade n or in, femoral shaft fractures associated with other fractures of the same femur, fractures in immature skeleton and segmental fracture were excluded. Winquist and Hansen classification was used to classify fracture comminution. Patients were alternately allocated. In the plating group, primary bone grafting was done in all cases. Time to union in nailing group was 16.43t2.48 weeks and in plating 19.88 \pm 3.46 weeks, $p$-value $<0.05$. Mean hospital stay in nailing group was 12.8 \pm 2.75 day and plating group $21.1 \pm 2.73$ days, $p>0.05$. There were 2 deep infections in the plating group and none in nailing group. There was no shortening of limb in die plating group but 2 patients in the nailing group had shortening of $2 \mathrm{cms}$. Delayed union occurred in 2 patients in nailing group but 5 in plating group. One patient in the nailing group had external rotation of at least 10 degrees and none in plating group. Two patients in the nailing group had knee stiffness and 6 patients in me plating group. One patient in the nailing group had a broken interlocking screw 2 patients in the plating group had bent plates. Closed interlocking intramedullary nailing as a method of treating closed communited femoral shaft fracture is better than plating in terms of rate of postoperative complication including infection.
\end{abstract}

Key Words: Comminuted fractures shaft of femur, static interlocking nailing and bridge plating.

\section{INTRODUCTION}

Fractures of the shaft of the femur are the result of high-energy trauma and therefore can be life-threatening injuries and can cause severe permanent disability. Shortening of the limb and malalignment, along with contracture of knee due to prolonged immobilization have traditionally plagued the orthopaedists' management of patients who have these injuries. ${ }^{2}$

Comminution is a sign of even higher energy injury and its presence traditionally has complicated the decision making on preferred treatment. The risk of shortening, rotation and malalignment are clearly higher in comminuted fractures.

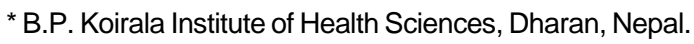

Address for correspondence : Dr. Bikram Prasad Shrestha

B.P. Koirala Institute of Health Sciences, Dharan, Nepal.

Email: bikramshrestha@yahoo.com

INMA Sentemher - Ortnher 20ก4 4.3 
Closed Comminuted fracture of the femoral shaft may be treated operatively by closed static interlocking nailing or by Dynamic Compression Plate (DCP) across the comminution as a bridge plate. ${ }^{3}$ Intramedullary nailing has many theoretic and practical advantages over me other forms of external and internal fixation. Nails are inserted with relatively less exposures and dissection as compared to that needed for plate fixation. Because the fracture hematoma is not evacuated with closed nailing, the early action of local cellular and humoral agents critical to normal fracture healing is not disturbed. The most accurate reduction of comminuted fractures of the femoral shaft can be obtained with interfragmentary compression and plate fixation. ${ }^{14}$ Magerl et a ${ }^{7}$ recommended primary bone grafting in fractures with suboptimal fixation, devascularization of fragments or cortical deficiency. Nowadays the interlocking nailing is regarded as the operative technique of choice for patients with a fracture of the femoral shaft. ${ }^{13}$ However, the advantages and disadvantages of the techniques have rarely been compared with plate osteosynthesis in clinical studies. ${ }^{13}$

\section{AIMS AND OBJECTIVE}

To compare me following aspects amongst patients treated by IM nailing and DCP fixation of comminuted femoral shaft fractures

1. Time to Union

2. Hospital stay (including readmission)

3. Wound infection

4. Shortening of limb

5. Delayed union

6. Malunion

7. Joint stiffness

8. Implant failure-bent or broken (nail and plate)

\section{MATERIAL AND METHODS}

In a prospective study a total of 54 patients, age (16 to 66) years, having closed comminuted fracture shaft of femur were treated by DCP - 22 patients, and interlocking nail-24 patients. Eight patients were lost to follow up. The study was conducted on patients admitted in Service Hospital, Department of Orthopaedics and Ittefaq Hospital, Lahore, Pakistan from June 1996 to Dec 1997. Written consent was taken regarding the type of surgery to be performed. Grade n or HI open fracture, shaft fracture associated with other fractures of the same femur, fracture in immature skeleton and segmental fracture and fractures in which external fixation had been applied were excluded. Winquist and Hansen classification was used to classify the fracture comminution. We have considered delayed union to be present if clinical union of fracture did not take place within 24 weeks of the operation. ${ }^{1}$

Initial assessment and necessary resuscitation were earned out. Thereafter the patients were put on proximal tibial skeletal traction. Patients were alternately allocated to the two treatment groups.

After interlocking nailing, on the first postoperative day, gentle range of motion exercise of me knee and hip was started. Toe touch crutch walking was started as early as possible (second or third day), and quadriceps strengthening exercise within limits of pain tolerance. Partial weight bearing with crutches was started when early callus formation was evident. Full weight bearing was allowed when callus formation bridged the fracture gap. Routine dynamization was not attempted.

In the plating group, primary bone grafting was done. On me first postoperative day, gentle ROM exercise of knee and hip were started. Quadriceps strengthening exercises were not encouraged at this stage. Non-weight bearing ambulation was started as early as possible. When radiological fracture union occurred, partial weight bearing was allowed and aggressive quadriceps strengthening exercise were begun and continued for one month. After one month of partial weight bearing, full weight bearing was started.

In both me groups sutures were removed on the $10^{\text {th }}$ postoperative day. The second follow up visit was 6 weeks from me date of surgery. Further visits were at 6 weeks intervals.

\section{RESULTS}

The most common cause of the fracture shaft of femur in our study was RTA (76\%). Table I shows me modes of injury encountered our study.

The most common type and site of fractures were as mentioned in (table II and III) respectively.

\section{Time to union}

Time to union in nailing group was $16.43 \pm 2.48$ weeks and in plating group was $19.88 \pm 3.46$ weeks, p-value $<0.05$.

\section{Postoperative Hospital stay (Including readmissions)}

Postoperative mean hospital stay in nailing group was $12.8 \pm 2.75$ day and $21.1 \pm 2.73$ days, $p>0.05$ in plating group.

\section{Wound infection}

There was no deep infection in me nailing group but 2 in me plating group. 
Table I : Mode of Injury

\begin{tabular}{l|cc}
\hline \multicolumn{1}{c|}{ Mode } & No. of Patients & \% \\
\hline Road Traffic Accidents & & \\
$? \quad$ Motor vehicle accidents & 6 & 13 \\
$? \quad$ Auto-pedestrians accidents & 12 & 26.1 \\
$? \quad$ Motorcycle accidents & 6 & 37 \\
\hline Fall from height & 3 & 13 \\
\hline Fall at ground level & 2 & 6.5 \\
\hline Hit by heavy object & $\mathbf{4 6}$ & 4.3 \\
\hline \multicolumn{1}{c|}{ Total } & $\mathbf{1 0 0}$ \\
\hline
\end{tabular}

Table II : Comminution classification (Winquist - Hansen) n=46

\begin{tabular}{cc|c|c|cc|c}
\hline \multirow{2}{*}{ Type } & \multicolumn{2}{c|}{ Nailing } & \multicolumn{2}{c}{ Plating } & \\
\cline { 2 - 7 } & Number & $\mathbf{\%}$ & Number & \% & Total & \% \\
\hline Type I & 6 & 13 & 7 & 15.2 & 13 & 28.2 \\
\hline Type II & 9 & 19.6 & 9 & 19.6 & 19 & 39.2 \\
\hline Type III & 7 & 15.2 & 4 & 8.7 & 11 & 23.9 \\
\hline Type IV & 2 & 4.3 & 2 & 4.3 & 4 & 8.7 \\
\hline Total & $\mathbf{2 4}$ & $\mathbf{5 2 . 2}$ & $\mathbf{2 2}$ & $\mathbf{4 7 . 8}$ & $\mathbf{4 6}$ & $\mathbf{1 0 0}$ \\
\hline
\end{tabular}

Table III : Location of fractures

\begin{tabular}{l|c|c}
\hline \multicolumn{1}{c|}{ Location } & No. of Patients & Percentage \\
\hline Proximal third & 12 & 26.1 \\
\hline Middle third & 25 & 54.3 \\
\hline Distal third & 9 & 19.6 \\
\hline Total & $\mathbf{4 6}$ & $\mathbf{1 0 0}$ \\
\hline
\end{tabular}

Table IV : Postoperative complications

\begin{tabular}{l|cc}
\hline \multicolumn{1}{c|}{ Complication } & Nailing (24) & Plating (22) \\
\hline Deep infection & 0 & 2 \\
\hline Knee stiffness & 2 & 4 \\
$\quad$ Flexion 100-120 & 0 & 2 \\
$\quad<100^{0}$ & & - \\
$\quad \begin{array}{l}\text { Implant failure } \\
\quad \text { Broken interlocking screw }\end{array}$ & 1 & 2 \\
$\quad$ Broken plate & - & 1 \\
\hline Loosening of screws & - & 0 \\
\hline External rotation 10 & 1 & 5 \\
\hline Delayed union & 2 & $\mathbf{1 6}$ \\
\hline Shortening 2 cm & 2 & \\
\hline \multicolumn{1}{c|}{ Total } & $\mathbf{8}$ & \\
\hline
\end{tabular}

\section{Shortening of limb}

One case had shortening of $2 \mathrm{~cm}$ in the nailing group but none in the plating group.

\section{Delayed union}

There was 2 case of delayed union in the nailing group but 5 in the plating group.

\section{Malunion}

There was one case of more than 10 degrees of external rotation in the nailing group and none in the plating group.

\section{Joint stiffness}

Two patients in the nailing group had knee stiffhess and 6 in the plating group.

\section{Implant failure}

There was one case of broken interlocking screw in the nailing group and 2 cases of bent plate in the plating group.

Postoperative complication were as mentioned in (Table IV). Intraoperative difficulties of significance were not encountered. 
Table V : Comparison of treatments of femoral shaft fracture : Closed nailing and plating with present study

\begin{tabular}{|c|c|c|c|c|c|c|c|}
\hline $\begin{array}{l}\text { Authors } \\
\text { and year }\end{array}$ & $\begin{array}{c}\text { No. of } \\
\text { patients }\end{array}$ & $\begin{array}{c}\text { Delayed } \\
\text { union }\end{array}$ & infection & $\begin{array}{c}\text { ROM knee } \\
<120^{0} \\
\end{array}$ & $\begin{array}{c}\text { Implant } \\
\text { failure }\end{array}$ & $\begin{array}{c}\text { Time to } \\
\text { union }\end{array}$ & Hospitalization \\
\hline $\begin{array}{l}\text { Magerl et al } \\
\text { (plate) } 1979\end{array}$ & 67 & & $3 \%$ & & $7(10.4 \%)$ & & 7 weeks \\
\hline $\begin{array}{c}\text { Reudi et al } \\
\text { (plate) } 1979\end{array}$ & 131 & & $6 \%$ & & $9(6.9 \%)$ & & \\
\hline $\begin{array}{c}\text { Cheng et al } \\
\text { (plate) } 1985 \\
\text { Thoresen } 1985 \\
\text { Nailing }\end{array}$ & $\begin{array}{l}32 \\
48\end{array}$ & & $\begin{array}{l}0 \% \\
0 \%\end{array}$ & & $2(6.3 \%)$ & $\begin{array}{l}22 \text { weeks } \\
16 \text { weeks }\end{array}$ & 4.5 weeks \\
\hline $\begin{array}{c}\text { Wiss (nailing) } \\
1966 \\
\text { Johnson and } \\
\text { Greenberg } 1987 \\
\text { Nailing } \\
\end{array}$ & $\begin{array}{l}112 \\
179\end{array}$ & & $0 \%$ & $0 \%$ & & 14 weeks & \\
\hline $\begin{array}{c}\text { Christe et al } \\
\text { (nailing) } 1988\end{array}$ & 117 & $2(1.7 \%)$ & & & $2(1.7 \%)$ & 17 weeks & \\
\hline $\begin{array}{l}\text { Bostman et al } \\
\text { (plating) } 1989 \\
\end{array}$ & 102 & $5(4.9 \%)$ & $7(6.86 \%)$ & & $5(4.9 \%)$ & & \\
\hline $\begin{array}{c}\text { Niekerk and } \\
\text { Schoots } 1992 \\
\text { plate }\end{array}$ & 20 & 0 & 0 & & & & \\
\hline $\begin{array}{l}\text { Niekerk and } \\
\text { Schoots } 1992 \\
\text { nailing }\end{array}$ & 19 & $15 \%$ & $10 \%$ & & & & \\
\hline $\begin{array}{l}\text { Mahnood et al } \\
\text { (nailing) } 1993\end{array}$ & 50 & $6 \%$ & & $1(2 \%)$ & & & \\
\hline $\begin{array}{c}\text { Riemer et al } \\
1994 \\
\text { Plating }\end{array}$ & 150 & & 0 & $1 \%$ & $7 \%$ & 18 weeks & \\
\hline $\begin{array}{l}\text { Ghaloo et al } \\
1997 \text { Plating } \\
\end{array}$ & 29 & $17(58.6 \%)$ & $8(27.5 \%)$ & $15(52 \%)$ & $3(10.3 \%)$ & & \\
\hline $\begin{array}{l}\text { Preset study } \\
\text { (plating) }\end{array}$ & 22 & $5(22.7 \%)$ & $2(9 \%)$ & $6(27.3 \%)$ & $2(9 \%)$ & 19.9 weeks & 27 days \\
\hline $\begin{array}{l}\text { Present study } \\
\text { (nailing) }\end{array}$ & 24 & $1(4.2 \%)$ & 0 & $2(8.3 \%)$ & $1(4.2 \%)$ & 16.4 weeks & 12 days \\
\hline
\end{tabular}

\section{DISCUSSION}

After reviewing the articles, (Table V) on the treatment of comminuted femoral shaft fracture by closed interlocking nailing and plating we did not find any prospective study comparing me two methods of treatments. In this regard this study can be considered to be the first of its kind. Before me advent of interlocking nailing, plating was considered appropriate for comminuted fracture of the femur, especially for those distal to the isthmus, where simple nailing was inadequate. ${ }^{11}$ Wherever, facilities for interlocked nailing became available, most Orthopaedic surgeons started treating fractures shaft of femur by interlocked nailing rather than plating, $m$ the case of plating, in type I and type $n$ comminution, attempts were made to anatomically reduce the fracture and compression was achieved. In type III and type IV, only those butterfly fragments were replaced which were necessary to determine anatomic length, axis and cortex. No attempt was made to perfectly reduce the medial cortex. Every attempt was made to disturb the intervening fragments as little as possible. Fixation of comminuted fracture without opening the fracture site has been advocated, a method mat has been termed as "Biological fixation". ${ }^{8}$ Technically, it was observed in our study that it was easier to operate on higher grade of comminution than on type I or type II. It is well recognized that fracture comminution may increase during reaming or nail insertion. The preoperative radiography may fail to detect non-displaced fracture line. ${ }^{6}$ It is important that me starting point for nail insertion be correct. ${ }^{6}$ The successful closed reduction of femoral shaft fractures may be impossible when there is soft tissue interposition at the fracture site. Mahaisavariya et al reported this in a retrospective study comparing the sonographic finding in soft tissue interposition with those in a control series of 40 others fractures.

On an average, the time to union in the case of plating was 3.5 weeks later than in the case of nailing group. We have considered delayed union to be present if clinical union of 
fracture did not occur within 24 weeks of the operation!. Higher incidence of delayed union was a significant disadvantage in the plating group. Since our study of individual cases extended for a period of 6 months follows-up, we are not in a position to comment on non-union. So for the purposes of calculation, we have excluded those cases which had not united in 6 months, when considering time to union. At the end of 6 months we had 2 cases in the nailing group, which had not united, and 5 cases from the plating group. If we had included these cases also, the differences in the time to union woud have been much more.

The main reason for the longer duration of hospital stay in the plating group (21-1 days) as compared to nailing (12.8 days) was mat the 2 cases that developed deep infection had to be admitted 4 times each to control the infection.

There was no deep infection in nailing group but in case of plating $2(9 \%)$ infections were noted. This rate is much more than that reported by Magerl et $\mathrm{al}^{7}(3 \%)$ and Reudi et $\mathrm{al}^{11}$ $(6 \%)$ but similar to that reported by Ghaloo et al ${ }^{4}(8 \%)$ and Bostman et al ${ }^{1}(7 \%)$. Higher rate of infection again was a significant disadvantage in the plating group.

In contrast to nailing group in which we had 2 cases of shortening of at least $2 \mathrm{~cm}$, there was no shortening in plating group. No other study mentions about shortening.

The fracture was fixed in at least 10 degrees of external rotation in the case of nailing, which was not seen in me case of plating.

One another important disadvantage of plating was the higher rate of knee stiffness. The other studies about plating have not mentioned about knee stiffness but Ghaloo et $\mathrm{al}{ }^{4}$ have reported $52 \%$ of cases in which knee flexion was less than 120 degrees.

We had one case of broken interlocking screw, which is not a major complication, but me bent plates in the plating group are major complications.

\section{CONCLUSION}

Plating of shaft of femur was associated with more (16) complications as compared to plating (8). Closed static interlocking intramedullary nailing as a method of treating closed comminuted femoral shaft fracture is better than plating in terms of rate of postoperative complication including infection. But because closed interlocking nailing requires image intensifier and fracture table, which is still not available in most of the hospitals, orthopaedic surgeons still need to know the techniques of plating comminuted femoral shaft fractures.

\section{REFERENCE}

1. Bostman 0, Yarjonen L, Vainiopaa S et al. Incidence of local complications after Intramedullary nailing and after plate fixation of femoral shaft fractures J Trauma 1989;29:63945.

2. Bucholz RW, Brumback RJ. Fractures of the shaft of femur .In: Rockwood CA, Green DP, Bucholz RW, Heckman JD, eds. Fracture in adults. Philadelphia: Uppincot Raven Publishers 1996; 1827-1918.

3. Chrisovitsinos JP, Xenakis $\mathrm{T}$, Papakostides $\mathrm{KG}$ et al. Bridge plating osteosynthesis of 20 conminuted fractures of the femur. Acta Orthop Scand 1997; 68:72-76.

4. Ghaloo MA. Comminuted femoral shaft fractures: Open intramedullary nailing versus plating. The Joumal of Pakistan Orthopaedic Association 1997; 14:17-22.

5. Johnson $\mathrm{KD}$, Johnston $\mathrm{DWC}$, Parker $\mathrm{B}$. Comminuted femoral shaft fractures: treatment by rotter traction, cerclage wires and an mtramedull lary nail or an interlocking nail J Bone Joint Surg 1984; 66-A: 1222-35.

6. Johnson KD, Greenberg M. Comminuted femoral shaft fractures: Orthop clin North Am 1987; 18:133-47.

7. Mageri $\mathrm{F}$, Wyss A, Brunner $\mathrm{C}$, Binder W. Plate osteosynmesis of femoral shaft fractures in adults: a follow up study. Clin Orthop 1979; 138:62-73.

8. Mahaisavariya B, Songcharoen $\mathrm{P}$, Chotigavamch Charoen. Soft tissue interposition of femoral fractures. Detection by ultrasonography during closed nailing . J Bone Joint Surg 1995; 77-B: 788-90.

9. Maini PS. Biological fixation of comminuted femoral shaft fractures follow up stuoty of nine years. The Joumal of Pakistan Orthopaedic Association 1997; Vol. 9 (supplement) .

10. Riemer B, Butterfield S, Burke C, Mathews D. Immediate plate fixation of highly comminuted femoral diaphyseal fractures in blunt pofytrauma patients. Orthopaedics 1992; 15:907-916.

11. Ruedi TP, Luscher JN. Results after internal fixation of communited fractures of the femoral shaft with DC plates. Clin Orthop 1979; 138:74-76.

12. Sprenger TR. Fractures oflhe shaft of femur treated with a single AO plate. South Med J 1983; 76:471-74

13. Van Niekerk JIM, Schools FJ. Femoral shaft fractures treated with plate fixation and interlocked nailing: A comparative retrospective study. Injury 1992; 23:219-22.

14. Winquist RA, Hansen ST. Comminuted fractures of the femoral shaft treated by Intramedull lary nailing. Orthop Clin North Am 1980; 11:633-47.

15. Wiss DA, Fleming CH, Matta JM, Clark D. Comminuted and rotationatty unstable fractures of the femur treated with an interlocking nail. Clin Orthop 1986; 213:35-47.

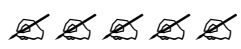

